\title{
Analytical Study of Causes, Effects and Remedies of Traffic Congestion in Nigeria: Case Study of Lagos State
}

\author{
Nwaigwe D.N, Amiara Chidiebere A, Okwunze C. Felix and Egege C.C.
}

Nigerian Building and Road Research Institute

Federal Ministry of Science and Technology

Nigeria

\begin{abstract}
Road traffic congestion remains a global phenomenon that plagues the cities in Nigeria; especially Lagos state, resulting in massive delay, unpredicted travel times, increased fuel consumption and monetary loss. The phenomenon has arisen from the poorly planned road network and traffic management, resulting in elongated and unbearable traffic jams. Lagos - a megacity with over 12 million people is chosen as a typical case study, being the fastest growing city in Nigeria. It is prevalent greatly during weekends, public holidays and periods of major activities. Major causes of the congestion include lane indiscipline, high traffic density, low road network carrying capacity, poor traffic management and support infrastructure, low response to the removal of broken down and crashed vehicles. This paper sets out to identify the diverse patterns of road traffic congestion in relation to human, road traffic environment and causative factors in a Nigeria's major city of Lagos, being the commercial nerve center of Nigeria with a view to recommending some cost-effective and sustainable policy options for a better and enhanced intraurban mobility. The paper recommends the integration of an enduring urban traffic planning and management strategies, such as effective mass transit, strict land-use adherence, effective traffic control and enforcement and integration of traffic management institutions, the mechanism at discouraging excessive car usage.
\end{abstract}

Keywords: Road traffic, Congestion, Lagos state, Transportation.

\subsection{INTRODUCTION}

Mobility is vital to functionality of cities as it affects their socio-economic activities. It is also a fact that the economic development of a nation is closely linked to its transport system. Hindrance to effective mobility is road traffic congestion, which the World Bank stated that it constitutes about 58.5\% of all noticeable urban transport externalities [1]. This is as a result of the ever increasing urbanization, human activities and the resultant heavy dependence on road transportation that warrants increase in the number of vehicles, of different categories on the road.

Of curiosity also is the difficulty of movements on inter-city roads and other major corridors due largely to obstructions such as traffic crashes, broken down vehicles or certain land use activities located along these corridors or absolute traffic volume exceeding the road network capacity during festive seasons and some other major activities. The demand for transport especially in Lagos State has been on the increase following the rapid socio-economic growth and development of this state. For instance, the rate of motor vehicle ownership and use is growing faster than population in many places, with the vehicle ownership growth rates rising to between 15 and 20 percent per year [2]. Traffic management has been quite poor in Lagos State, despite the growth in transport demand and supply. The resultant traffic congestion has become obstruction to our livelihood.

Road traffic congestion, according to [3] can be defined as the impedance vehicles impose on each other, due to the speed-flow relationship, in conditions where the use of a transport system approaches its capacity. [4] also defined congestion as the infiltration of road network capacity due to regular and irregular reductions in service quality exemplified by increased travel times, variation in travel times and interrupted travel. [5] simply described road traffic congestion as an imbalance between the inflow and the outflow of vehicles into and out of a particular space. This is also in line with [6] conceptualization of road traffic congestion as a situation when urban road network could no longer accommodate the volume of traffic on it. 


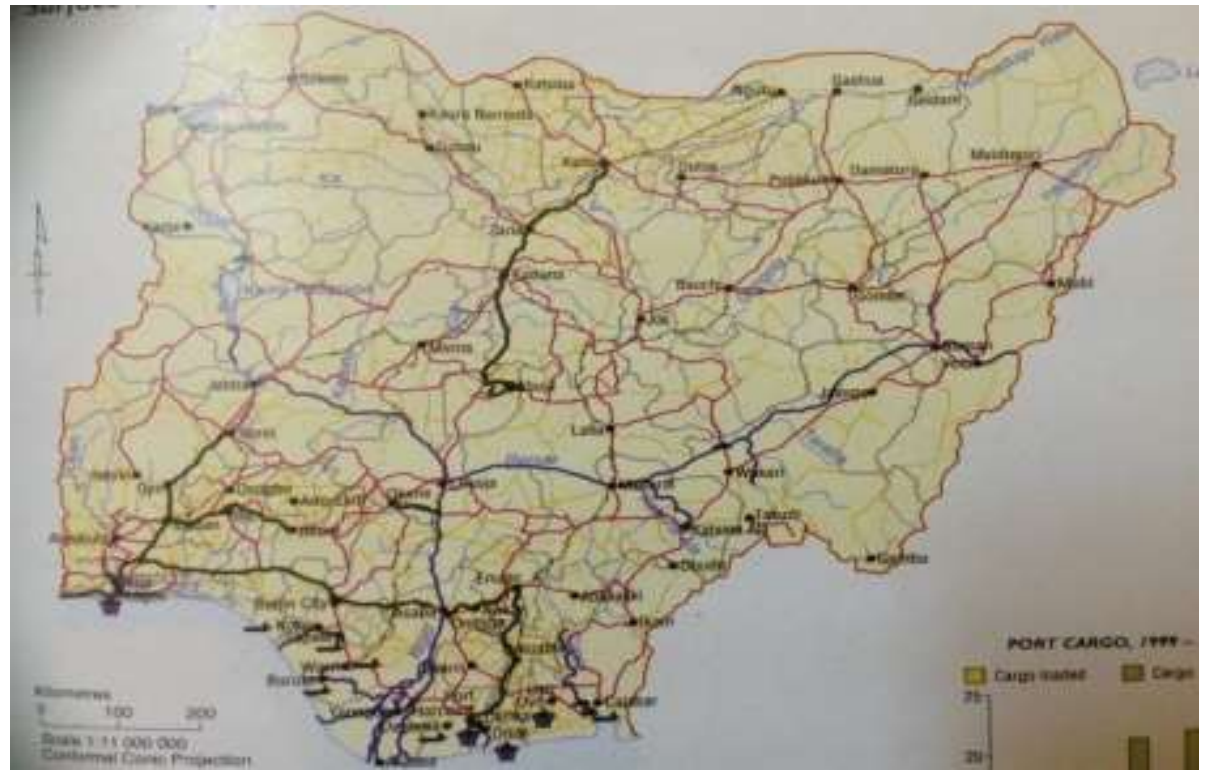

Figure1.1: Road Map of Nigeria

\subsection{AIM AND OBJECTIVES}

The aim of this paper is to determine the causes of traffic congestion in Nigeria and provide remedial measures using Lagos state as a case study. The objectives are: 1) to provide facts about the study area. 2) to enumerate the different types of congestion cost 3 ) to determine the cause of congestion in the city 4) to provide proactive and congestion management strategies.

\subsection{CONSIDERED AREAS}

\subsection{Lagos State}

Lagos state is situated within latitude $6^{\circ} \mathrm{N}$ and latitude $23^{\circ} \mathrm{Nand}$ longitude $2^{\circ}$ Eand longitude $42^{\circ} \mathrm{E}$. Lagos is a mega city in the South Western part of the country. The more built up Mainland and Lagos Island make up the areas referred to as Metropolitan Lagos which accounts for about $80 \%$ of the population of the state (Merem and Twumasi, 2008). Lagos with Population of 9,013,534 according to the National Population Census of 2006 is about $6.4 \%$ of the country's population.[7] stated that while Nigeria's population density is 100 persons per square kilometer, that of Lagos is about 2,400 persons $\mathrm{km} 2$ with annual population growth of 5.0 to $5.5 \%$. It should also be noted that the Lagos State Government citing the United Nations' estimates among others disputed the official Population figure for Lagos as it believed the Population of the city should be around 20millon people (Lagos state government, 2006).

Lagos with an area of 3,577 square kilometers is the smallest state in terms of land area in Nigeria. It represents only $0.4 \%$ of the country [7]. However, the Federal Road Safety Corps records on vehicles and drivers revealed that Lagos with its $0.4 \%$ land mass, even with about $60 \%$ under water, accommodates about $25 \%$ of total vehicles and drivers in Nigeria. In terms of relating the road network capacity with the vehicular population, while the national vehicle per kilometer is about 16, Lagos has about 200. Road, water, air and rail transport modes are in use in Lagos, but the road mode accounts for more than $80 \%$ of all movements[8]. Lagos has a total of 117 federal roads of $509.97 \mathrm{~km}, 3,028$ of State Government roads totaling 5,816.71 km and 6,451 Local Government roads of $3,573.7 \mathrm{~km} \mathrm{[8].}$

\subsection{CONGESTION CHARGES}

Traffic congestion constrains the growth of Gross Domestic Product (GDP), [9] as it continues to impact negatively on cities economic environment. The consequences of traffic congestion include productivity loss, change in accident frequency and characteristics, increase in air pollutants and emissions, increased vehicle operating costs and increased noise nuisance [9]. The resultant effect could include relocation of businesses and homes from congested areas to more favorable locations forcing down the values for land and houses in addition to degradation of other economic values in such areas.

The effects of road traffic congestion are visible on the economy, infrastructures, environment and health. The actual economic impacts of traffic congestion can differ from one area to other, depending on its economic profile and business location pattern. [10] examined how various producers of economic goods and services are sensitive to congestion, through its impacts on business costs, productivity and output levels. As a result, it recognized different types of congestion costs, such as: operating cost, travel cost, man-hour loss, pressure on road infrastructure, global warming, and health challenges. 


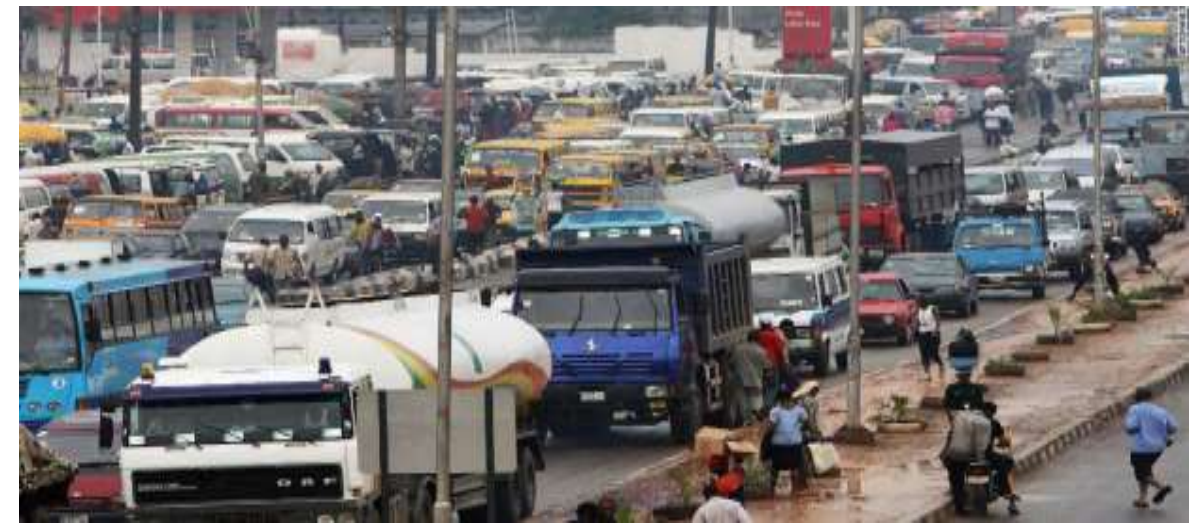

Plate 3.1: Traffic congestion in Lagos

\subsection{CAUSES OF CONGESTION}

\subsection{Vehicular Density}

Once the vehicular density exceeds the designed capacity of a road network, a 'dead weight' or traffic congestion sets in and the intensity increases with more vehicles getting to the spot than leaving the point as shown in [11] that congestion can be categorized into recurrent and non- recurrent congestion. Recurrent congestion is caused by factors that relate to rapid growth in population, urbanization and related growth in car ownership and use. Recurrent congestion occurs mainly when there are too many vehicles at the same time, consequently reducing traffic speed and increasing personal commuting time. This occurs typically during peak hours but can also occur off- peak i.e. at other weekday hours and during the weekend. On the other hand, non-recurrent congestion is associated with random conditions or special and unique conditions, including traffic incidents (ranging from disabled vehicles to major crashes), work zones which slow traffic down and weather and special events. From this definition, the drivers, both the patient and the impatient, are responsible for the traffic build- up. Non recurrent congestion is associated with random, special and unique conditions such as obstructions from broken down vehicles, road traffic crashes and weather hence very difficult to predict and tackle.

\subsection{Urbanization and Increased Motorization.}

Urbanization and increased motorization without corresponding increase in infrastructure and transport services is a major cause of congestion. [12] postulated that the traffic congestion problem of Lagos is the imbalance in the travel supply-demand in the road traffic environment. The imbalance, according to him is visible to the geometric increase in the level of motorization and population of the city, without a commensurate level of growth in the provision of road traffic infrastructure, as well as multimodal mass transit facilities.

\subsection{Dominance of Low Capacity Minibus Taxi}

Introduction of the Bus Rapid Transit (BRT) as shown in Plate 3.1 in Lagos in 2008 to serve major corridors and the underconstruction LRT in the neighborhood of Okokomaiko, Iddo and Marina, which is isolated from vehicular traffic are meant to ease congestion and improve mobility in the city. The BRT which relies on the use of dedicated lanes separated from the main traffic is fast and reliable. Lagos Metropolitan Area Transport Authority records indicate that the system uses 220 buses to move more than 200,000 passengers daily between the hours of 06.00 and 22.00 . The records also showed that over 400 million passengers have been conveyed in the last five years of the BRT operation in the state [13-14] .Most companies drag goods and petroleum products by road. These are conveyed to distance places by articulated vehicles. Fuel depots are often located along major highways. The parking lots provided for waiting vehicles are by the road side. At the peak of time, the park spaces are full and those that cannot be accommodated within the parking lots park along the road side, this further narrows the road and hinder flow of traffic. 


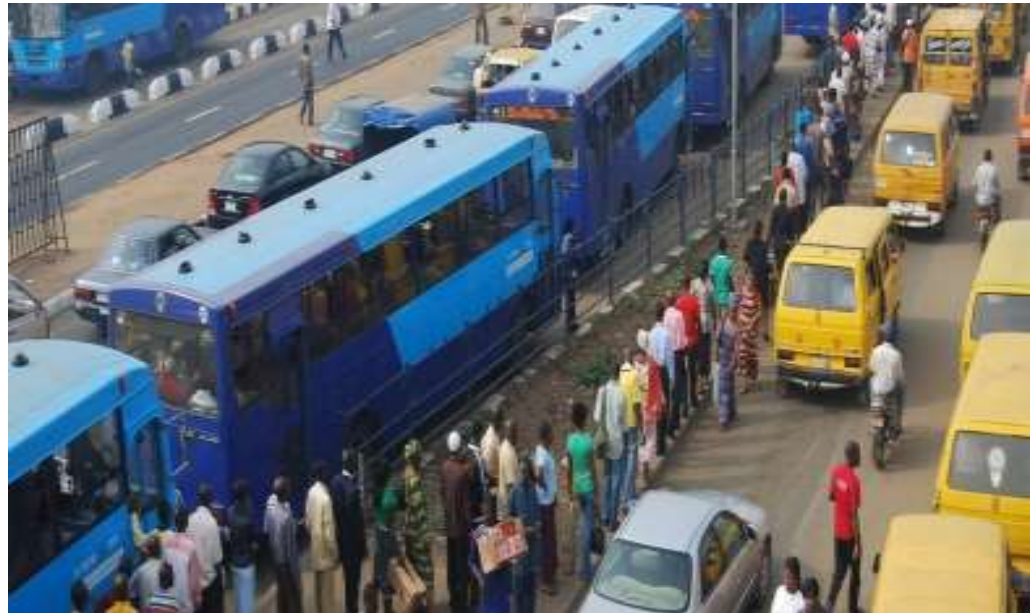

Plate 4.1: Bus Rapid Transit in Lagos

4.4

Improper Land Use

Rapid urbanization without proper land use planning especially in the location of certain specialized activities such as concentration of workplaces in some areas, residential and recreational facilities in some other areas and often far from each other results in crisscrossing movements compounding traffic problems. Most often, traffic impact assessments are not carried out before facilities are located in the cities. The problem is more severe during the peak hours as most people resume and close from work respectively in the morning and evenings at the same time. Inappropriate placing of certain facilities such as having many of the high traffic attracting religious worship centers on the Lagos-Ibadan expressway also constitute major traffic nuisances.

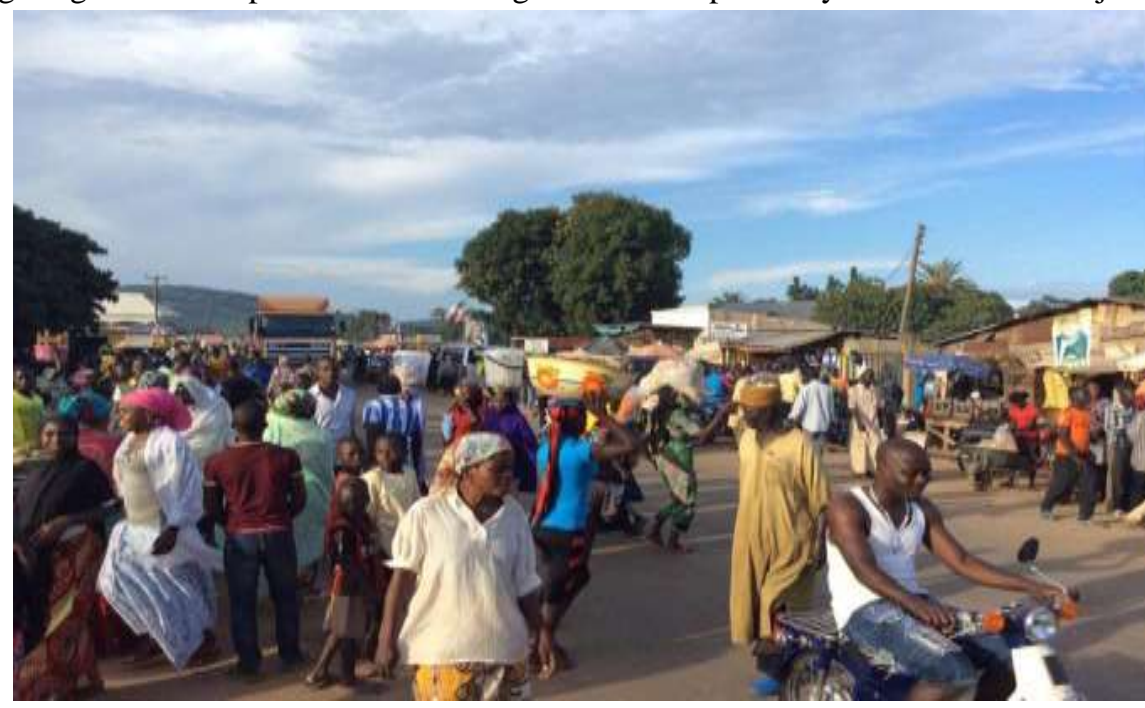

Plate 4.2: A Market Located On A Major Nigerian Road

\subsection{Frequent Breakdown of Vehicles and Road Traffic Crashes}

In most of the developing countries, particularly in Nigeria, most of the vehicles on the roads are used vehicles, popularly known as 'tokunbo' imported from Europe or America. The maintenance culture is very poor. Such vehicles, left at the mercy of near illiterate mechanics and fake spare parts vendors, often break down and cause the already narrow road to further get choked. Broken down vehicles, and those involved in crashes that are not immediately cleared away from the road often cause traffic to build up as shown in Plate 4.2 and hence the inevitable resultant traffic congestion. 


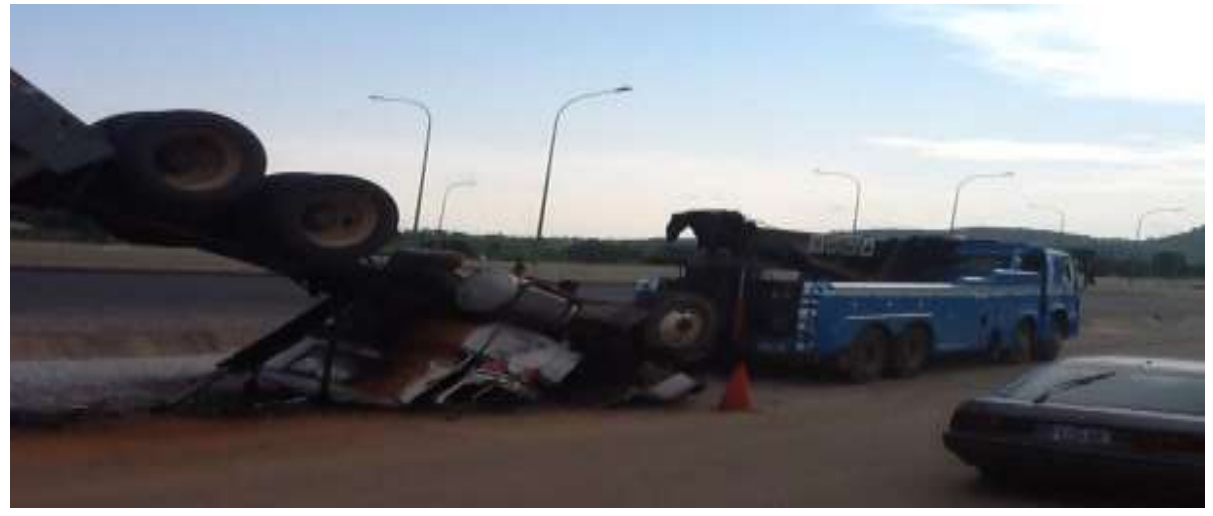

Plate 4.3: FRSC removing obstruction away from the road

\subsection{METHODOLOGY}

A web-based selection survey was done to ascertain the perception of professionals on the causes, effects and solutions of traffic congestion in Lagos state. The road traffic of eight towns within Lagos was considered. The towns are Ikeja, Agege, Mushin, Yaba, Oshodi, Ajah, Lekki and Iyana Ipaja. This study employed the use of both Primary and secondary data. The Lagos Metropolitan Area Transport Authority provided data on traffic for the selected roads. A cross sectional survey of 598 commuters was carried out to obtain information from road users within the study area on traffic congestion and factors responsible for congestion. This study was analyzed using likert scale, mean, standard deviation and importance index.

Table 2.1: Population and sample scope

\begin{tabular}{|c|c|c|}
\hline Towns & Population & Sample Size \\
\hline Ikeja & 365,250 & 85 \\
\hline Agege & 478,563 & 64 \\
\hline Mushin & 687,589 & 72 \\
\hline Yaba & 547,546 & 66 \\
\hline Oshodi & 654,879 & 59 \\
\hline Ajah & 546,660 & 68 \\
\hline Lekki & 600,556 & 79 \\
\hline Iyana Ipaja & 587,550 & $\mathbf{5 9 8}$ \\
\hline Total & $\mathbf{4 , 4 6 8 , 5 9 3}$ & \\
\hline
\end{tabular}

Table 2.1 shows various towns, population and sample size considered in this study. These towns are known to usually face traffic congestion, gird locks, traffic jams and so on. From a total population of four million, four hundred and sixty-eight thousand five hundred and ninety three for the towns considered, a sample size consisting of 598 commuters were considered for the research.

\subsection{Importance Index}

Importance Index $=\sum \frac{W}{H * N}$

Where:

$\mathrm{W}=$ weight given to each factor by the respondents and ranges from 1 to 4 , (where "1" is "not prevalent" and "4" is "highly prevalent"); $\mathrm{H}=$ highest weight (i.e. 4 in this case) and;

$\mathrm{N}=$ total number of respondents.

\subsection{MEAN}

Mean gives the average of a set of data. It could be grouped or ungrouped. 
International Journal of Engineering Research And Advanced Technology, Vol.5, Issue 9, September-2019

$\bar{X}=\frac{x_{1}+x_{2}+x_{3}+\cdots \ldots \ldots \ldots+x_{n}}{N}$

\subsection{STANDARD DEVIATION}

Standard deviation (SD) describes how much a value is deviated from the mean. If SD is low then such value is close to the mean.

$\sqrt{\frac{\sum f(x-\bar{x})}{N}}$

Where,

$\mathrm{F}=$ frequency

$\mathrm{N}=$ total number in the set

$\mathrm{x}=$ each value in the set

$\bar{x}=$ Mean value

Table 2.2: Locations and respective traffic volumes

\begin{tabular}{|c|c|c|c|c|c|c|c|c|c|c|}
\hline Location & Time & Cars & Bicycle & $\begin{array}{l}\text { Small } \\
\text { Trucks }\end{array}$ & $\begin{array}{l}\text { Heavy } \\
\text { trucks }\end{array}$ & Motorcycles & $\begin{array}{l}\text { Large } \\
\text { buses }\end{array}$ & $\begin{array}{l}\text { Mini } \\
\text { bus }\end{array}$ & Coaster & Total \\
\hline $\begin{array}{l}\text { Agege- } \\
\text { Oshodi }\end{array}$ & $\begin{array}{l}\text { 7am-12 } \\
\text { pm }\end{array}$ & 6987 & 1 & 1500 & 1958 & 3650 & 5698 & 4587 & 2987 & 27368 \\
\hline $\begin{array}{l}\text { Toll gate- } \\
\text { Oshodi }\end{array}$ & $\begin{array}{l}7 \mathrm{am}-12 \\
\mathrm{pm}\end{array}$ & 5984 & 2 & 889 & 1578 & 3540 & 5016 & 4506 & 2587 & 24102 \\
\hline $\begin{array}{l}\text { Oshodi- } \\
\text { Mushin }\end{array}$ & $\begin{array}{l}\text { 7am-12 } \\
\text { pm }\end{array}$ & 4687 & 1 & 678 & 1487 & 3490 & 4950 & 3900 & 2490 & 21683 \\
\hline $\begin{array}{l}\text { Oshodi- } \\
\text { Yaba }\end{array}$ & $\begin{array}{l}\text { 7am-12 } \\
\text { pm }\end{array}$ & 4005 & 2 & 995 & 1300 & 3200 & 4500 & 3500 & 2500 & 20002 \\
\hline $\begin{array}{l}\text { Agege- } \\
\text { Mushin }\end{array}$ & $\begin{array}{l}\text { 7am-12 } \\
\text { pm }\end{array}$ & 4650 & 1 & 1005 & 1200 & 3500 & 4650 & 3600 & 2600 & 21206 \\
\hline $\begin{array}{l}\text { Agege- } \\
\text { Ikeja }\end{array}$ & $\begin{array}{l}\text { 7am-12 } \\
\text { pm }\end{array}$ & 3950 & 2 & 1250 & 1300 & 3550 & 4800 & 3500 & 2450 & 20802 \\
\hline $\begin{array}{l}\text { Oshodi- } \\
\text { Ajah }\end{array}$ & $\begin{array}{l}\text { 7am-12 } \\
\text { pm }\end{array}$ & 3860 & 0 & 860 & 1400 & 3900 & 4760 & 3580 & 2648 & 21008 \\
\hline $\begin{array}{l}\text { Lekki } \\
\text { oshodi }\end{array}$ & $\begin{array}{l}\text { 7am-12 } \\
\text { pm }\end{array}$ & 4568 & 0 & 990 & 2140 & 4200 & 5068 & 3890 & 3580 & 24436 \\
\hline $\begin{array}{l}\text { Oshodi- } \\
\text { Mile } 2\end{array}$ & $\begin{array}{l}\text { 7am-12 } \\
\text { pm }\end{array}$ & 4500 & 0 & 840 & 1550 & 3945 & 4870 & 3685 & 3680 & 23070 \\
\hline $\begin{array}{l}\text { Berger- } \\
\text { Ota }\end{array}$ & $\begin{array}{l}\text { 7am-12 } \\
\text { pm }\end{array}$ & 5595 & 0 & 990 & 1400 & 3860 & 4950 & 3500 & 3880 & 24175 \\
\hline $\begin{array}{l}\text { Apapa } \\
\text { wharf- } \\
\text { iyana } \\
\text { ipaja }\end{array}$ & $\begin{array}{l}\text { 7am-12 } \\
\text { pm }\end{array}$ & 4820 & 0 & 850 & 1200 & 3586 & 4500 & 3250 & 3750 & 21956 \\
\hline
\end{tabular}

Table 2.2 shows locations and traffic volumes for various modes of transportation within the towns considered. The time for each mode of transportation is constant, cars were found to contain the highest number of traffic volumes followed by large buses. The least are bicycles and small trucks. 
International Journal of Engineering Research And Advanced Technology, Vol.5, Issue 9, September-2019

Table 2.3: Causes of traffic congestion and importance index

\begin{tabular}{|c|c|c|c|c|}
\hline $\begin{array}{l}\text { Causes of Traffic } \\
\text { Congestion }\end{array}$ & Mean & $\begin{array}{l}\text { Standard } \\
\text { deviation }\end{array}$ & Importance index & Rank \\
\hline Poor road condition & 3.46 & 0.87 & 0.74 & 1 \\
\hline $\begin{array}{l}\text { Disobeying traffic laws } \\
\text { by drivers and the } \\
\text { motorist }\end{array}$ & 3.25 & 1.02 & 0.68 & 2 \\
\hline Indiscriminate parking & 3.05 & 0.71 & 0.65 & 3 \\
\hline $\begin{array}{l}\text { Vehicular break down } \\
\text { on the road }\end{array}$ & 2.98 & 0.69 & 0.63 & 4 \\
\hline $\begin{array}{l}\text { Insufficient parking } \\
\text { spaces }\end{array}$ & 2.87 & 0.67 & 0.60 & 5 \\
\hline $\begin{array}{l}\text { Insufficient road } \\
\text { network and routes }\end{array}$ & 2.76 & 0.63 & 0.59 & 6 \\
\hline $\begin{array}{l}\text { Rough driving and bad } \\
\text { habits while driving }\end{array}$ & 2.69 & 0.89 & 0.55 & 7 \\
\hline Accident along the road & 3.46 & 1.05 & 0.49 & 8 \\
\hline $\begin{array}{l}\text { High population in the } \\
\text { area }\end{array}$ & 3.25 & 0.92 & 0.47 & 9 \\
\hline $\begin{array}{l}\text { Inadequate amount of } \\
\text { traffic light }\end{array}$ & 3.05 & 0.75 & 0.45 & 10 \\
\hline $\begin{array}{l}\text { Over dependence on } \\
\text { road as the main mode } \\
\text { of transportation }\end{array}$ & 2.98 & 0.85 & 0.40 & 11 \\
\hline $\begin{array}{l}\text { Increase in the number } \\
\text { of vehicle along this } \\
\text { road }\end{array}$ & 2.69 & 0.68 & 0.39 & 12 \\
\hline $\begin{array}{l}\text { Trading and } \\
\text { commercial activities }\end{array}$ & 2.89 & 0.79 & 0.36 & 13 \\
\hline $\begin{array}{l}\text { Insufficient number of } \\
\text { traffic wardens/officials }\end{array}$ & 3.12 & 0.88 & 0.34 & 14 \\
\hline $\begin{array}{l}\text { Movement of people and } \\
\text { goods from residential } \\
\text { to commercial/industrial } \\
\text { areas }\end{array}$ & 3.20 & 0.91 & 0.32 & 15 \\
\hline $\begin{array}{l}\text { Inadequate traffic } \\
\text { monitors }\end{array}$ & 2.99 & 0.85 & 0.3 & 16 \\
\hline $\begin{array}{l}\text { Dominance of low } \\
\text { capacity mini bus }\end{array}$ & 2.87 & 0.76 & 0.28 & 17 \\
\hline Improper land use & 2.95 & 0.88 & 0.26 & 18 \\
\hline Urbanization & 2.84 & 0.96 & 0.24 & 19 \\
\hline Road repairs & 2.69 & 0.85 & 0.21 & 20 \\
\hline
\end{tabular}

Table 2.2 shows the various causes of traffic congestion as obtained from the commuters. Poor road condition (Importance index $=0.74$ ), disobeying traffic laws by drivers (Importance index $=0.68$ ) and indiscriminate parking (Importance index $=0.65$ ) are the leading causes of traffic congestion.

Table 2.3: Effects of traffic congestion and importance index

\begin{tabular}{|l|l|l|l|l|}
\hline EFFECTS & Mean & Standard deviation & Importance index & Rank \\
\hline $\begin{array}{l}\text { Higher chance of } \\
\text { collisions }\end{array}$ & 4.61 & 0.76 & 0.86 & 1 \\
\hline $\begin{array}{l}\text { Late arrival for } \\
\text { business leading to } \\
\text { personal losses }\end{array}$ & 4.37 & 0.78 & 0.78 & 2 \\
\hline Air Pollution to & 4.29 & 0.83 & 0.75 & 3 \\
\hline
\end{tabular}


International Journal of Engineering Research And Advanced Technology, Vol.5, Issue 9, September-2019

\begin{tabular}{|l|l|l|l|l|}
\hline environment in & 3.98 & 0.96 & 0.73 & 4 \\
\hline $\begin{array}{l}\text { Loss } \\
\text { productivity }\end{array}$ & 4.05 & 0.84 & 0.7 & 5 \\
\hline Road rage & 0.87 & 0.65 & 6 \\
\hline $\begin{array}{l}\text { Inability to forecast } \\
\text { travel time }\end{array}$ & 4.11 & 0.84 & 0.62 & 7 \\
\hline $\begin{array}{l}\text { Fuel wastage } \\
\text { Wear and tear on } \\
\text { vehicles }\end{array}$ & 3.89 & 0.83 & 0.59 & 8 \\
\hline $\begin{array}{l}\text { Blocked traffic and } \\
\text { hinder emergencies }\end{array}$ & 3.79 & 0.91 & 0.49 & 9 \\
\hline $\begin{array}{l}\text { Spill over effect } \\
\text { from congested } \\
\text { main arteries }\end{array}$ & 3.59 & 0.83 & 0.41 & 10 \\
\hline
\end{tabular}

Table 2.3 shows the various effects of traffic congestion as obtained from the commuters. Higher chance of collisions (Importance index $=0.86$ ) and late arrival for business leading to personal losses (Importance index $=0.78$ ) are the leading effects of traffic congestion and spill over effect from congested main arteries the least (Importance index $=0.41$ ).

Table 2.4: Remedies to traffic congestion and importance index

\begin{tabular}{|c|c|c|c|c|}
\hline REMEDIES & Mean & Standard deviation & Importance index & Rank \\
\hline Expand capacity & 4.35 & 0.75 & 0.87 & 1 \\
\hline $\begin{array}{l}\text { Improve } \\
\text { connectivity }\end{array}$ & 4.26 & 0.74 & 0.75 & 2 \\
\hline Closure of key links & 3.96 & 0.87 & 0.70 & 3 \\
\hline $\begin{array}{l}\text { Increase traffic } \\
\text { lights }\end{array}$ & 3.81 & 0.92 & 0.65 & 4 \\
\hline $\begin{array}{l}\text { Improved road } \\
\text { design }\end{array}$ & 3.76 & 0.86 & 0.63 & 5 \\
\hline $\begin{array}{ll}\text { Regular } & \text { road } \\
\text { maintenance } & \end{array}$ & 3.99 & 0.84 & 0.59 & 6 \\
\hline $\begin{array}{l}\text { Building competing } \\
\text { modes }\end{array}$ & 4.08 & 0.76 & 0.57 & 7 \\
\hline $\begin{array}{l}\text { Adequate } \\
\text { information for } \\
\text { routers }\end{array}$ & 4.15 & 0.72 & 0.52 & 8 \\
\hline Improved locating & 3.99 & 0.65 & 0.48 & 9 \\
\hline $\begin{array}{l}\text { Improved } \\
\text { scheduling }\end{array}$ & 3.84 & 0.62 & 0.45 & 10 \\
\hline Walking or biking & 3.67 & 0.58 & 0.43 & 11 \\
\hline $\begin{array}{l}\text { Clear and Traffic } \\
\text { Guidance }\end{array}$ & 3.65 & 0.55 & 0.41 & 12 \\
\hline $\begin{array}{l}\text { Smart systems } \\
\text { should be engaged }\end{array}$ & 3.54 & 0.53 & 0.38 & 13 \\
\hline $\begin{array}{l}\text { Accident Detection } \\
\text { Technology }\end{array}$ & 4.01 & 0.51 & 0.35 & 14 \\
\hline $\begin{array}{ll}\text { Expansion } & \text { of } \\
\text { Transport } & \\
\text { Infrastructure } & \end{array}$ & 4.05 & 0.99 & 0.31 & 15 \\
\hline
\end{tabular}

Table 2.4 shows the various remedies to traffic congestion as obtained from the commuters. Expand capacity (Importance index $=0.8$ ), improve connectivity (Importance index $=0.75$ ) and improved road design (Importance index $=0.70$ ) are the leading remedies of traffic congestion and expansion of transport infrastructure the least (Importance index $=0.31$ ). 


\subsection{CONCLUSION}

The enormous causes of Traffic congestion in Lagos have compelled developing workable strategies which of course include huge deployment of technology to address the situation. Lagos has had a lot of strategies tested with some jettisoned and others working to improve the livability of the Megacity which is fast growing. New strategies must emerge to tackle or mitigate the ever present traffic congestion in the city. The non-recurring traffic congestion on major inter-city corridors such as; Lagos-Ibadan and Abuja-Lokoja also deserve the sustained attention of all traffic management institutions in Nigeria. It is hoped that the solutions proffered in this paper will assist smooth committing on our major corridors and in making the city of Lagos and other similar urban centers better places to live in.

\section{REFERENCES}

1. Armah J. (2010). A Systems Dynamics Approach to Explore Traffic Congestion and air pollution link in the city of Accra, Ghana. www.mdpi.com/journal/sustainability.

2. Banjo A. (1984). Towards a new framework for Urban Transport Planning in Third World Cities. Proceeding Australian Road Research Board Conference, Vol. 12, No. 1pp 177.

3. Chakwizira O. (2001). The Question of Road Traffic Congestion and Decongestion in the greater Johannesburg area. www.mdpi.com/journal/sustainability.

4. Federal Road Safety Corps. (2013). Flying vehicles on Nigerian Roads. A Publication of the Federal Road Safety Corps Produced by the Policy, Research and Statistics Department.

5. Goodwin E. (1997). Solving Congestion. Inaugural lecture for the Professorship of Transport London University College. http://cts.ucl.ac.uk/tsu/pbginau.htm, pp 1-11.

6. Lagos State Government (2006).Road Statistics, LSMW \& Office of Infrastructure. Lindsay Transportation Solution. pp 1-25.

7. Merem, E. And Twumasi, Y.A. (2008). Using Geospatial Information Technology in Natural Resources Management: The Case of Urban Land Management in West Africa, Sensor, 8, www.mdpi.org/sensors, pp 607-619.

8. McGregor. S. And Mahinga. D. (2014). "Traffic Costs Nairobi $\$ 570,000$ a day as new Africa Hub"- boomberg.com. pp 3165.

9. Odeleye A. (2008). A study of Road Traffic Congestion in selected Corridors of Metropolitan Lagos. www.mdpi.org/sensors, pp 400-458.

10. Oyeyemi B. (2003).Strands in Road Traffic Administration in Nigeria. C.M Konsult, Ibadan pp 40-58.

11. Odeyemi C. (2015). Corps Marshal and Chief Executive FRSC address to the Officers and Men of the Federal Road Safety Corps during his Official visit to the Lagos Command of the FRSC on 2nd February, 2015.

12. Sanders (2015). Congestion in work zones Webinar. Barriersystemsmic.com. pp 24-48

13. Taiwo, S. (2005). 'The Case of Lagos: Air Quality Improvement Project'. A Position paper. Lagos Metropolitan Area Transport Authority (LAMATA), Lagos, Nigeria, pp4-7.

14. World Bank. (1999). Sustainable Transport: Priorities for Policy Reform. Washington D.C. www. Wikipedia.com 